\title{
A concepção de vida em Gregório de Nissa Ensaio de aproximações com as ciências da Vida (Parte II)
}

\author{
Lina Boff e Eva Aparecida Rezende de Moraes
}

\section{Introdução}

Este artigo se propõe completar um outro, intitulado "A concepção de vida em Gregório de Nissa", publicado nesta mesma Revista em setembro/dezembro de $2007^{1}$. No primeiro, depois de havermos apresentado breves traços biográficos do teólogo e místico, abordamos, de seus escritos, a concepção bíblico-teológica de vida em todas as suas dimensões, priorizando a vida humano-cristã, no sentido teológico de seus escritos. A seguir, tentamos algumas aproximações com o nosso conceito de vida hoje, nas ciências modernas.

Agora, com este artigo, buscamos abordar a concepção de vida eterna em algumas das obras de Gregório de Nissa e tentar uma aproximação com o conceito da continuidade da vida ou eternidade, nas ciências, uma vida verificável que nos é apresentada pelo saber científico dos nossos dias. Este artigo é apresentado em duas partes. Na primeira, extraímos a concepção de vida eterna do padre capadócio no comentário e interpretação que ele faz a versículos específicos do livro do Cântico dos Cânticos, sua interpretação e

\footnotetext{
${ }^{1}$ ATUALIDADE TEOLÓGICA / 27, ano 11, 2007, p. 317-341. Nesse primeiro artigo as autoras apresentam a concepção de vida em Gregório de Nissa em três partes: na primeira esboçam traços biográficos deste padre da igreja, falam da concepção de vida entre os gregos e da ousadia da inovação. Na segunda parte buscam sistematizar a concepção de vida como um novo nascimento, uma nova vida e um novo modo de viver. E na terceira parte aproximam a concepção teológica de vida em Gregório de Nissa com as Ciências da vida hoje.
} 
comentário sobre A Vida de Moisés e a um versículo do Eclesiastes, considerado por ele livro "divinamente inspirado". É o que a seguir veremos.

$\mathrm{Na}$ segunda parte, ensaiamos algumas aproximações entre a teologia de Gregório de Nissa e as ciências da vida - citamos a física e, principalmente, a atual biologia. Partimos da física, porque a vida começa nos átomos e moléculas, e nos deteremos na biologia, por ser atualmente a área que mais tem oferecido novos paradigmas. Ao lado da física e da biogênese, deveríamos acrescentar outros campos científicos (arqueologia, estudos do genoma, medicina em geral, psicologia, entre outras...), tarefa que exigiria maior espaço e tempo. Mas acreditamos que as aqui referidas já nos dão conta da enormidade de trabalho que a atual situação científica tem colocado à teologia.

Prosseguimos, levando em consideração não só aproximações e assertivas, mas também distinções existentes entre a teologia e as ciências modernas, nas quais estivemos atentas ao estudo sobre a vida como mistério, a vida como realidade da evolução e, finalmente, a necessidade da morte para que haja vida. Aguardamos a contribuição crítico-construtiva dos leitores-as interessados-as.

\section{A concepção de vida eterna em Gregório de Nissa}

Para esta concepção, tomamos alguns discursos que o bispo capadócio elaborou e pronunciou em momentos especiais litúrgicos da vida da comunidade de fé, em sua diocese de Constantinopla. Ver-se-á o sentido de vida eterna nas homilias feitas por ele, nas quais relaciona vida eterna como à voz que chama pelo nome; como a visão de Deus; e vida eterna como nascimento e morte. Veremos, a seguir, cada um desses conceitos atribuídos à vida eterna pelo teólogo em estudo.

\subsection{Vida eterna: a voz que chama pelo nome}

Entramos aqui no comentário que Gregório de Nissa elabora sobre o Livro do Cântico dos Cânticos ${ }^{2}$. Esse livro da Sagrada Escritura é um dos mais misteriosos pela sua colocação: ele parte da revelação de Deus ao ser humano e da revelação do próprio ser humano ao seu Criador. O mais importante comentário sobre esse livro não é o do teólogo nisseno, mas o

\footnotetext{
${ }^{2}$ AA.VV., da Coleção l'ora di lettura, commentata dai padri della chiesa/, 1-8 volumes, seguindo o tempo litúrgico, Bologna, Dehoniane, 1974-1976: GREGORIO DI NISSA, bispo, "Commento al Cantico dei Cantici", em l'ora di lettura/2, PG 44,8028, p. 372 . Ver também, a cura di BONATO, V., Omelie sul Cantico dei Cantici, Bologna, Dehoniane, p. 93ss.
} 
comentário de Orígenes ${ }^{3}$, padre da igreja do início do segundo século (ca. 185-250). Sobre o caminho traçado por Orígenes - que inspirou inumeráveis padres da igreja - Gregório de Nissa interpreta a busca da esposa do Cântico dos Cânticos como a atitude, o comportamento, a busca da criatura de fé, que descobre dentro de si mesma um desejo de vida ${ }^{4}$. Esse desejo torna-se, então, relação mística, certeza, abandono ao Amor Maior, do qual o desejo mesmo se reconhece gerado por esse Amor.

A pessoa descobre dentro de si mesma uma aspiração direcionada a um mistério que a supera: o desejo de Deus. No transfundo da concepção de vida eterna em Gregório de Nissa, elaboramos três formas de expressão utilizadas por ele: (i) através da voz divina que chama pelo nome a pessoa amada: “... ouvirei a tua voz; e por causa de tua voz, dá-me a vida eterna" (Ct 1,6 (Vulg.); (ii) através do ensinamento que nutre e abre para a vida eterna: "Ensina-me, amado de minha alma, onde apascentas, onde descansas o rebanho..." (Ct 1,7); (iii) através da água - íntima conexão que faz com o Novo Testamento -, água que faz da criatura que a bebe, "uma fonte de água jorrando para a vida eterna" (Jo 4,14). Do comentário do teólogo, destacamos a primeira forma de expressão:

Onde apascentas, ó bom pastor, tu que trazes sobre teus ombros todo o rebanho? Pois, a única ovelha que trazes sobre teus ombros, representa toda a natureza humana... Chama-me pelo nome, para que eu, parte de toda a humanidade, possa auscultar a tua voz e com essa possa ter a vida eterna ${ }^{5}$.

Nesta primeira forma de expressão, o autor em estudo enfatiza a voz do amado, que chama pelo nome a pessoa amada. Das palavras da amada é que se sabe que o amado é também pastor. A pessoa amada faz parte do redil que Ele apascenta e é parte da humanidade toda. Os ensinamentos que nos

\footnotetext{
${ }^{3}$ MANZANARES, C. V., Dizionario sintético di Patristica, Cittá del Vaticano, Librerria Editrice Vaticana, p. 137; Dicionário Patrístico e de Antiguidades Cristãs, Vozes e Paulus, 2002, p. 1045. Nasceu de uma família cristã de Alexandria e cedo lhe foi confiada à escola de catecúmenos da mesma cidade. Grande pregador em várias cidades como Atenas, Cesaréia e outras. Viveu como homem espiritual, teólogo especulativo e exegeta crítico. Para um estudo mais aprofundado: Cf. a cura di RAMELLI, Ilaria, Gregório di Nissa. Sull anima e la resurrezione. Il pensiero occidentale, Milano, Universitá Sacro Cuore, 2007, p. 113ss.

${ }^{4} \mathrm{Cf}$. CHÊVENERT, J., L'Eglise dans le commentaire d'Origène sur le Cantique des Cantiques, Bruxelles, 1969, p. 212.

5 L'ora di lettura commentata dai padri della chiesa/8, Bologna, Dehoniane, 1976, p.372373. Fazer um cf., A cura di, BONATO, V., Omelie sul Cantico dei Cantici, Bologna, Dehoniane, 1995, p. 93-109.
} 
são oferecidos desse comentário, nos impulsionam a desejar a contemplação dos bens que transcendem a condição humana da criatura e que são apresentados na figura do pastor, do rebanho e da voz que chama pelo nome a pessoa amada. O pastor não se dedica apenas ao seu rebanho, mas carrega sobre seus ombros a humanidade toda. É nesse contexto que Gregório de Nissa elabora sua teologia mística ao comentar o livro do Cântico dos Cânticos. A segunda forma de expressão foi assim destacada:

Ensina-me, amado de minha alma, onde apascentas, onde descansas o rebanho... (Ct 1,7). Faça-me saber onde fica, para que eu possa encontrar neste lugar saudável o alimento que nutre, sem o qual não posso entrar na vida eterna ${ }^{6}$.

Nesta segunda forma de expressão, o teólogo em estudo fala em continuidade da primeira forma de expressão. A amada pergunta o lugar onde seu amado apascenta, ensina e nutre. A amada pede insistentemente que o amado lhe ensine onde ele pastoreia seu rebanho. Pois é nesse lugar que ela encontra o alimento que a nutre para poder entrar na vida eterna. Os ensinamentos que se pode extrair desse comentário são o valor do conhecimento com a finalidade do compreender para crer, é o intellego ut credam.

Gregório de Nissa considera como elemento essencial da existência cristã o alimento que dá vida eterna à pessoa amada. Por isso, o lugar onde se encontra esse alimento torna-se sempre uma busca incessante da pessoa amada, que pergunta: "onde apascentas, onde descansas o rebanho?". Pois, segundo o nisseno, esta expressão indica o tempo no qual a luz mais largamente se difunde sobre o mundo, e este dia é o mais próximo da sua origem divina e, portanto, mais pura é a luz deste dia?

A Sagrada Escritura caracteriza todos os seus escritos. Com extrema liberdade e eficácia, toma como ponto de partida a Sagrada Escritura, tanto o Antigo como o Novo Testamento, e faz íntima conexão de sua VII homilia sobre o Cântico dos Cânticos com o quarto evangelho:

Quem beber da água que eu lhe darei, nunca mais terá sede. Pois a água que eu lhe der, tornar-se-á nele uma fonte de água jorrando para a vida eterna (Jo 4,14).

${ }^{6}$ Cf., A cura di BONATO, V., Omelie sul Cantico dei Cantici, Bologna, Dehoniane, 1995, p. 6-11.

${ }^{7}$ Cf. PORSO, A., "La spiritualitá essenziale di Gregorio di Nissa", em Rassegna di Teologi$a / 5$, settembre-ottobre (2007), p. 725-744. 
Nesta terceira forma de expressão, Gregório de Nissa entra no Novo Testamento, conectando-se com a narrativa joanina do ensinamento do Mestre que pede água à samaritana no poço de Jacó (cf. Jo 4). Destaca em seu comentário, a célebre frase: “... a água que eu lhe der tornar-se-á nele uma fonte de água jorrando para a vida eterna”. Segundo o capadócio, a alma, alimentada pelo ensinamento que nutre para a vida eterna, necessita igualmente da água divina. Ele mantém um estilo elevado na sua argumentação racional. Comentaristas e teólogos estudiosos da obra gregoriana, tais como Daniélou, Von Balthasar e outros aqui citados, são quase unânimes em afirmar que, quem acorre à fonte de água que é o Verbo ${ }^{8}$, atinge dela a divina água que o Verbo oferece a quem tem sede. Para quem beber, esta água se tornará fonte de água que jorra para a vida eterna.

\section{Concluindo}

A concepção de vida eterna em Gregório de Nissa, extraída de seu comentário ao Cântico dos Cânticos, nos leva a sublinhar elementos raros para a literatura patrística da época e para a própria linguagem metafórica utilizada por ele ao elaborar sua teologia como padre da igreja capadócia. Ele fala de vida eterna explicitamente, por três vezes. Segundo a nossa interpretação, três elementos emergem desse seu comentário.

Como primeiro elemento teológico, tomamos a voz do amado que chama pelo nome sua amada: voz e nome, intimamente conectados. Por causa da voz do amado, é que a amada entra na vida eterna. A vida eterna, portanto, é aus-cultar - ouvir por dentro, escutar na profundidade da alma -, a voz do amado. É também participar das núpcias, do banquete que embeleza o clima de festa e satisfaz a continuidade da vida. Seria como que se sentir chamada constantemente pelo nome; segundo a reflexão teológica do nisseno, a viver a vida na sua essência.

\footnotetext{
${ }^{8}$ Retomamos o sentido desta palavra na teologia mística do nisseno: Cf. A cura di, BONATO, V., Omelie sul Cântico dei Cantici, o, c., p. 9-10. Segundo o comentarista, o Verbo sugere e aponta direcionando as ações humanas para a perfeição e supera continuamente novas etapas desta caminhada. O Verbo é a Palavra que sempre eleva a pessoa humana da sua condição limitada e a faz avançar no caminho. Ele se torna assim o Mistagogo, enquanto faz avançar e leva a perceber a comunidade de fé, a sua mesma voz. O Verbo, nos escritos de Gregório de Nissa, é o próprio Cristo. Daí o sentido da metáfora que ele interpreta do livro do Cântico dos Cânticos: "Levanta-te minha amada, formosa minha, vem a mim!" (Ct 2,10). No comentário feito no VI sermão das Bem-aventuranças, afirma que somente o Verbo revela plenamente o mistério de Deus. Cf., RAMELLI, Ilaria, Gregório di Nissa. Sull anima e la risurrezione, Milano, Bompiani, 2007, p. 1002ss.
} 
Os elementos voz e nome enchem o vazio da vida humano-divina que habita em toda a criatura que se sente chamada e que já goza da voz que a introduz na vida eterna porque a chama pelo nome - segundo elemento teológico. O contexto em que essa voz chama pelo nome da amada se dá em um lugar que evoca vida plena e serenidade constante.

$\mathrm{O}$ alimento que sacia e a água que dessedenta constituem o terceiro elemento teológico do comentário em estudo, pois jorram vida eterna. Desta concepção de Gregório de Nissa, tende-se a compreender a metáfora empregada por ele, quando descreve o encontro do amado com sua amada. Este se dá "ao meio-dia", momento em que o sol cai a pino e momento em que se desfazem todas as sombras. A luz, então, invade a pessoa amada e todas as expressões de desejo pronunciadas por essa, levam-na à compreensão do modo com que a felicidade tão desejada possa durar para sempre.

\subsection{Vida eterna: visão de Deus}

Entramos, aqui, nas homilias sobre as Bem-aventuranças ${ }^{9}$, que constituem parte do comentário ao livro sobre a Vida de Moisés ${ }^{10}$. Vários são os estudos feitos comentando essas homilias. Nós, porém, nos ativemos aos estudos e comentários da contemporaneidade. Trata-se de seu segundo tratado exegético sobre o Novo Testamento, que se constitui numa série de oito homilias. Nós tomamos o VI sermão em que Gregório de Nissa comenta e aprofunda o versículo 8 das Bem-aventuranças de Mateus:

Bem-aventurados os puros de coração porque verão Deus (Mt 5,8).

Nestas homilias, como faz em todos os seus escritos, o bispo de Nissa busca aproximar o Novo Testamento do Antigo, tomando deste último fundamento e atualização para interpretar e aplicar à vida de fé de seus contemporâneos. A pergunta que lhe inquieta tem seu ímpeto: é possível ver Deus e viver? Toda a tradição bíblica responde: Não. Mas, como Deus pode ter colocado no coração de sua criatura um desejo irrealizável? A esperança não é um produto da imaginação, um sonho apenas ou uma fantasia humana, mas

${ }^{9}$ GREGORIO DE NISSA, De beatitudinibus Oratio 6: PG 44, 1263-1266; traduzido pela CNBB com o título "Deus é um rochedo nacessível" e outra parte da mesma homilia com o título "A esperança de ver a Deus", em Liturgia das Horas II, Ofício das Leituras da $12^{a}$. Semana do Tempo Comum, respectivamente, pp. 362-363 e 366-368.

${ }^{10}$ Cf. DANiÉLOU, J., Gregoyre de Nysse. L avie de Moyse ou traité de la perfection em matiére de vertu, SCH I, Paris, 1955, citado por BAC II, Patrologia de la edad de oro de literatura patristica griega, Madrid, 1985, p. 295. 
tem seu fundamento no Filho de Deus, o Verbo, o Enviado do Pai para reconduzir a Ele toda a humanidade. A pureza de coração é o nascimento da nova criatura, que nasce da água e do Espírito, que nos torna aptos a ver Deus.
Ver Deus, conforme as Escrituras, significa ter, possuir Deus em si mesmo. Por exemplo: Vejas os bens de Jeru- salém, é o mesmo que (dizer): encontres tais bens. (...) Por conseguinte, quem vê Deus, pelo fato mesmo de vê- lo, obteve todos os bens: possui a vida sem fim, a eterna incorruptibilidade, o reino sem fim, a alegria contínua, a verdadeira luz, a glória intangível, a perpétua exultação ${ }^{11}$.

Segundo o nisseno, a promessa de felicidade, proposta pela esperança de ver Deus, apresenta proporções de longo alcance. Contudo, o modo de ver Deus repousa na pureza de coração. Para esse bispo, a figura de Moisés (de Vita Moysis) ${ }^{12}$ é interpretada de forma alegórica: o grande líder espiritual de Israel se converte no símbolo da migração e ascensão mística a Deus, mesmo que vendo a Deus não se possa continuar vivendo (cf. Ex 33,20).

O nosso propósito, aqui, é destacar as afirmações teológicas que manifestam o desejo de Moisés de ver Deus e a sua glória e, por outro lado, a exigência feita pelas bem-aventuranças para chegar ao mistério de Deus que não pode ser visto, mas que se pode chegar a Ele, de onde se alcança ver todas as coisas de outro ângulo, o ângulo da vida feliz da eternidade ${ }^{13}$. Daí a exigência de se viver a pureza de coração, como propõe a Bem-aventurança de Mateus: "Bem-aventurados os puros de coração porque verão Deus" (Mt $5,8)$.

Em tal contexto e ao fazer uma aproximação da eternidade com a contemplação, o teólogo nisseno toma uma citação do Evangelho joanino para afirmar que "ninguém jamais viu a Deus: o Filho único que está voltado para o seio do Pai, este o deu a conhecer" (Jo 1,18); e conclui: "mas não o mostrou em seu mistério". Segundo o teólogo capadócio, "Deus aqui é proposto à contemplação daqueles que purificaram o coração (...)”. Por conseguinte, se são felizes todas as pessoas que afirmam estarem na contemplação de

\footnotetext{
${ }^{11}$ l'ora di lettura commentata dai padri della chiesa./5, o. c., p. 308.

${ }^{12}$ DANIÉLOU, J., Gregoyre de Nysse. La vie de Moyse ou traité de la perfection em matiére de vertu, SCH 1, Paris, segunda edição de 1955, corrigida e aumentada, Paris, 1968, citado por BAC II, Patrología, la edad de oro de la literatura patrística griega, Madrid, 1985, p. 295.

${ }^{13}$ Cf. PORSO, A., "La spiritualitá essenziale di Gregorio di Nissa”, em Rassegna di Teologi$a / 5$, settembre-ottobre (2008), p. 743-745: quando escreve sobre a Perfeição que se alcança através da amizade verdadeira com Deus, traz o exemplo de Moisés que se fez conhecer de Deus, tornou-se amigo d'Ele, chamando-o de: "seu amigo" (filon autón).
} 
Deus acima das próprias forças, se a felicidade consiste nessa visão de Deus e se a Deus vê quem tem o coração puro, então está claro que a pureza de coração, que torna a criatura feliz, não está entre as coisas que nos são impossíveis ${ }^{14}$, porque todos podemos ser puros.

A teologia de Gregório de Nissa continua afirmando que se pode ver Deus sempre. Coloca, porém, a condição de que devemos nos dar conta de que o objeto da nossa busca está escondido, como que em uma densa nuvem, além do nosso campo visível. Segundo ele, o místico João - o evangelista -, que se encontrou nesta luminosa nuvem, faz uma afirmação negativa quando diz que, "Ninguém jamais viu Deus: o Filho único, que está voltado para o seio do Pai, este o deu a conhecer" (Jo 1,18). Com tal constatação, Gregório de Nissa estabelece que o conhecimento da essência divina é inatingível pelo ser humano, se a via for apenas o intelecto ${ }^{15}$. Nenhum conhecimento humano pode dar-nos uma idéia adequada da divindade ${ }^{16}$. Ver Deus é gozar a vida eterna. Se Deus é a vida, quem não vê Deus, não vê a vida ${ }^{17}$.

Nosso teólogo prossegue, dizendo que Paulo, com sua abrangente e profunda inteligência, confirma e acrescenta: "O Senhor dos senhores, o único que possui a vida eterna, habita uma luz inacessível, que nenhuma criatura viu e nem pode ver. A ele honra e poder eterno. Amém!" (cf. 1Tm 6,16). Esta forma doxológica de inspiração bíblica derruba nossa pretensão de apreender e de compreender o mistério de Deus, que nos envolve com sua vida e ao mesmo tempo sacia o nosso desejo de vê-lo com nossos olhos ${ }^{18}$. Nesse sentido, o ensinamento de Moisés, segundo o bispo em estudo, nos é claro e corta o pico da nossa montanha intelectual:

Não poderás ver a minha face, porque o ser humano não pode ver-me e continuar vivendo (Êx 33,20).

Com riqueza de expressões, dá um sentido profundo e verdadeiro à sua espiritualidade mística, afirmando que, Deus, rocha inacessível a toda investida do conhecimento humano, se doa a si mesmo aos puros de coração. Esta doação divina, muda o coração da sua criatura e lhe dá luz do conhecimento

\footnotetext{
${ }^{14}$ GREGÓRIO DE NISSA, "A esperança de ver a Deus", em Oficio das Leituras/III, tradução da CNBB, p. 367-368.

${ }^{15}$ Cf. GREGORIO DI NISSA, "La vita di Mosé: soltanto il Verbo rivela pienamente il mistero di Dio", em l'ora di lettura/5, o.c., p.299..

${ }^{16}$ GREGORIO DI NISSA, "La vita di Mosé 149," em l'ora di letura commentata dai padri della chiesa/5, o. c., p. 298-299.

${ }^{17}$ Cf. Ibidem, p. 298.

18 Somente o Verbo revela plenamente o mistério de Deus, em l'ora di lettura/5, ivi, p. 300.
} 
que a faz possuir Deus em seu mistério, sem precisar vê-1o ${ }^{19}$. O Verbo, portanto, abraça sua criatura e a conduz pela mão, a caminho do despojamento e da pobreza em espírito, onde pode encontrar o Deus que se esconde de quem o busca com desejo e sede do seu mistério Único e Verdadeiro ${ }^{20}$. Na mesma homilia, é sublinhada a limitação da inteligência humana, que busca incessantemente o conhecimento do mistério de Deus. Segundo ele,
a mente que penetra com a mais intensa e perfeita atenção na inteligência das realidades, quanto mais avança na con- templação, tanto mais toma consciência de que a natureza divina é invisível ${ }^{21}$.

\section{Concluindo}

Percebe-se, aqui, que o autor em estudo conserva um estilo elevado em todas as páginas que escreve, cheias de imagens e argumentações racionais. Nas suas várias e ricas problemáticas que levanta, faz referência contínua à Sagrada Escritura. Nesta, a profundidade da cultura não o impede de reforçar a santidade da vida e a ortodoxia da fé. Para ele, ver Deus é possuí-lo em si mesmo. Afirma que só os puros de coração poderão ver Deus. E mais: todos nós podemos ver Deus porque todos podemos viver puros de coração. Toma a figura de Moisés - grande líder do povo de Israel -, e o transforma no símbolo da migração terrena e da ascensão mística a Deus, mesmo que o autor sagrado em sua narrativa, diga que, vendo a Deus não se pode continuar vivendo. Por outro lado, toma João 1,18, em que afirma: ninguém jamais viu a Deus, só o Filho que o deu a conhecer. Aqui se encontra a resposta das questões levantadas pelo próprio nisseno.

Em afirmações contraditórias como esta, o nisseno quer dizer que a visão beatífica transcende todo o desejo humano. Deus é, por natureza, princípio de vida, e a sua essência não pode ser fechada em conceitos humanos. Conceber Deus partindo dos nossos conhecimentos e da nossa linguagem, significa não possuir a vida. Cabe lembrar que, na história do pensamento humano, Gregório aparece como aquele que rompeu com os vícios do pensamento arcaico, reabilitou o devir do tempo, dando-lhe um conteúdo positivo e, sobretudo, com sua teologia e sua mística, mostrou que a pessoa

19 Cf. PORSO, A., "La spiritualitá essenziale di Gregorio di Nissa", em Rassegna di Teologia/5, (2008), o. c., p. 736-740.

${ }^{20}$ Cf. Comentário da obra sobre a vida de Moisés, em l'ora di lettura/5, o.c., p. 299.

${ }^{21}$ Cf. Ibidem, p.299. 
humana não tem outra definição senão a de ser indefinível, porque, como criatura, existe e vive para o ilimitado de Deus.

\subsection{Vida eterna: nascimento e morte}

Aqui, entramos na sua homilia sobre o livro do Eclesiastes ${ }^{22}$, também conhecido como Coélet. A exata interpretação deste livro compreende oito homilias, que vão de $1,1-3,13$, as quais se propõem desenvolver a mesma intenção teológica e mística.

A interpretação alegórica que Gregório lhe dá, prova ser este livro, o Coélet, "divinamente inspirado", tendo como objetivo "elevar o espírito acima dos sentidos". Nesse processo de despojamento e de renúncia, o espírito guiará os sentidos a um mundo de $\mathrm{paz}^{23}$. Fortemente influenciado pelo pensamento platônico, Gregório sente toda a limitação do espírito humano e até mesmo sua inferioridade diante da Palavra, pois somente ela dá o verdadeiro conhecimento de Deus. Tímido e introvertido, o teólogo se revela plenamente, mesmo à revelia de seu conhecimento, quando comenta a Sagrada Escritura $^{24}$. Estuda e interpreta profundamente a conhecida frase do Eclesiastes (Coélet):

Há um tempo de dar à luz e um tempo de morrer (Ecl $3,2)$.

Está aqui muito bem expressa a necessária ligação que faz, ao unir a morte da nossa condição humana ao nascimento para a eternidade. Pois, obrigatoriamente, à morte da condição humana, segue-se o parto da dimensão eterna da vida em Deus.

Oxalá que a mim também suceda nascer em tempo querido e morrer em tempo oportuno ${ }^{25}$.

Segundo a teologia gregoriana, o Eclesiastes não se refere ao nascimento involuntário e nem à morte natural, "como se nisso houvesse uma reta

\footnotetext{
${ }^{22}$ GREGORIO DI NISSA, "Tempo di nascere e tempo de morire", traduzido pela CNBB com o título "Há um tempo de dar à luz e um tempo de morrer", Homilía 6: PG 44, 702-703, em Ofício das Leituras da $7^{a}$. Semana do Tempo Comum, p. 209-210. Ver também l'ora di lettura commentata dai padri della chiesa /2, Bologna, Dehoniane, 1975, p. 545.

${ }^{23}$ BAC II, o. c., p. 295.

${ }^{24}$ l'ora di lettura commentata dai padri della chiesa / 2, com a colaboração de vários autores, Bologna, Dehoniane, 1975, p. 544.

${ }^{25}$ l'ora di lettura commentata dai padri della chiesa/2, com a colaboração de vários autores, Bologna, Dehoniane, 1976, p.544-546.
} 
ação virtuosa; [Não há virtude em nascer e nem em morrer, pois] nunca se definirá como virtude ou vício aquilo que não está em nosso poder" ${ }^{\circledR 26}$.

A sua ânsia de eternidade e sua união com Deus falam com acentos muito fortes, ao manifestar toda a fadiga do espírito que procura em si mesmo a vida eterna. Esta não se encontra, senão, quando a pessoa humana se reconhece como criatura e filha de Deus. Para ele, o nascimento para a eterna visão de Deus e a morte da condição humana, são uma dinâmica que "escandem" ${ }^{27}$ o ritmo da vida, inexoravelmente; quer dizer com isso que, estes dois tempos tocam fortemente a vida do ser humano e de toda a criação, pois sem morte não há vida ${ }^{28}$.

Esta vida, da qual fala o nosso teólogo e místico, é vista e sentida, manifestada e vivida em seus elementos mais íntimos e obscuros ao mundo visível. É preciso, portanto, compreender o parto e o nascimento para a eternidade num tempo querido e compreender a morte da nossa condição humana e terrena num tempo oportuno.

\section{Concluindo}

Pode-se destacar três pontos que tocam mais diretamente a concepção de vida eterna na teologia de Gregório de Nissa.

Em primeiro plano, deve-se colocar a sua ânsia de eternidade explicitada em seu comentário ao Livro dos Provérbios, que comenta como livro "divinamente inspirado". Não esconde, porém, o trabalho penoso e difícil para se chegar a viver essa ânsia espiritual. Segundo ele, através desse trabalho da alma, gera-se, em estado de parto, a própria salvação. Nasce-se, então, para a vida eterna, em um nascimento pelo qual, "nós somos, de certo modo, pais de nós mesmos" 29 ."Há um tempo de dar à luz...".

Num segundo plano de sua teologia, nos damos de encontro com uma afirmação que se encontra ligada à primeira. Gregório de Nissa explica que tal processo forma em nós a imagem de Cristo que nasce dentro de nós e morre para plenificar este nascimento. A vida em Cristo transcende a tempo-

\footnotetext{
${ }^{26}$ Cf., Hom, 6: $P G$ 44, 702-703, citada pela tradução da CNBB, em Ofício das Leituras/III, p. 209.

${ }^{27}$ Do verbo "escandir" aplicado à métrica do verso. Foi aplicado com o sentido de "destacar", "marcar" esses dois grandes acontecimentos da vida humana que se abre para a vida definitiva, a vida eterna ou eternidade.

${ }_{28}$ l'ora di lettura commentata dai padri della chiesa/2, com a colaboração de vários autores, Bologna, Dehoniane, 1975, p. 544. Fazer um cf. com: Sull anima e la resurrezione, já citado, especificamente: "Saggio introduttivo", p. 207ss.

${ }^{29}$ TODDE, M. e GHINI, Emanuela, comentaristas do texto patrístico em l'ora di lettura commentata dai padri della chiesa/2, Bologna, Dehoniane, 1976, p. 545.
} 
ralidade, abre-nos para uma eternidade capaz de englobar em si o tempo e o espaço, porque o Deus Trino se manifesta ao mundo pelo mistério da Encarnação.

Finalmente, Gregório de Nissa sintetiza seu caminho de busca espiritual da eternidade do Deus Trino com a experiência de Paulo, que enfrentava a morte cada dia (cf. 1Cor 15,31), isto é, a morte de tudo aquilo que nos distancia da vida eterna de Deus. Esta é a morte oportuna. O efeito desta morte é o nascer num tempo querido, que nos abre para a vida eterna do Deus Trino. Viver a eternidade de Deus é, portanto, realizar a plena identidade que traz seu nome, gozar da visão beatífica no tempo que transcende a temporalidade da vida humana, e nascer para a plenitude do Cristo ressuscitado, o Vivente.

\section{Ensaios de aproximações entre a Teologia de Gregório de Nissa e al- gumas descobertas das ciências da vida ${ }^{30}$}

A seguir, apresentaremos um pequeno esboço de aproximações entre algumas descobertas científicas acerca da vida, do tempo e da eternidade com a teologia de Gregório de Nissa aqui apresentada. Essa não é uma tarefa fácil. Esse artigo é um ensaio. Muitas vezes, essa tentativa não se constrói devido às diferenças epistemológicas de ambos os campos - o científico e o teológico.

Primeiramente, temos que nos lembrar que os objetivos da ciência são determinar, do melhor modo possível, as características empíricas do mundo natural, e descobrir por que o mundo funciona de um jeito e não de outro ${ }^{31}$. Assim, geralmente, as ciências não buscam entender porque o mundo funciona, mas como ele funciona. As perguntas, então, são diferentes: as ciências perguntam como o mundo funciona e, a teologia, pergunta, essencial e primeiramente, o por quê de tudo o que existe.

Entretanto, uma aproximação pode ser possível. Ultimamente, ao voltar-se para perguntas fundamentais da existência do universo e da vida, tem surgido, nas diversas ciências, uma filosofia da ciência ${ }^{32}$ que busca respostas

\footnotetext{
${ }^{30}$ Entendemos "ciências da vida" aqueles saberes da atualidade que, de uma forma ou outra, se dedicam ao tema "vida" - especialmente a vida na Terra. Incluem, portanto, física, astrofísica, química, biologia e a quântica.

${ }^{31}$ Cf. GOULD, Stephen Jay, em ZIMMER, Carl. O Livro de Ouro da Evolução. O triunfo de uma idéia. Editora Ediouro. 2004, p. 9. EL-HANI, Charbel Nino; VIDEIRA, Antonio Augusto Passos (org.). O que é vida? Para entender a Biologia do século XXI, Editora Relume Dumará / FAPERJ, Rio de Janeiro, 2005, p. 17.

${ }^{32}$ Entendemos essa filosofia da ciência como a formação de um pensamento científico acerca da realidade, e não apenas a constatação experimental dessa realidade. Este último movimento
} 
mais profundas, para além das constatações do método experimental. Buscamos a seguir, uma aproximação entre essa filosofia das ciências da vida e a teologia de Gregório de Nissa.

\subsection{Retomando Gregório de Nissa}

Do estudo feito, vimos que o teólogo destaca alguns elementos acerca da vida e da eternidade, na primeira parte deste artigo - "Vida eterna: A voz que chama pelo nome"-, a parte relativa ao Cântico dos Cânticos. Estes elementos são: a voz divina que chama pelo nome a pessoa amada e lhe dá a vida eterna; o ensinamento que nutre a vida eterna; a água que faz da criatura que a bebe uma fonte jorrando para a vida eterna; a voz do amado que chama a pessoa amada, e esta, que se encontra apascentada em seu redil; a voz da amada que chama seu amado de pastor, representando toda a natureza humana; a vida eterna que vem com a voz do amado; o amado que apascenta, ensina e nutre; o lugar do pastoreio, onde a amada encontra o alimento para entrar na vida eterna.

Vimos também que o nisseno relaciona as imagens descobertas no texto veterotestamentário com as apresentadas no Novo Testamento: o ensinamento do Mestre que pede água à samaritana - quem bebe dessa água nunca mais terá sede. Observamos, aqui, uma inversão do texto veterotestamentário: neste, é a amada quem pede água da vida eterna ao amado; no texto joanino, é o Mestre (= amado) que pede água à samaritana (= amada). Assim, o primeiro elemento teológico de Gregório de Nissa é ouvir a "voz do amado"; o segundo elemento teológico é o encontro do amado e da amada, que se dá ao "meio-dia", quando o sol está a pino e não existem sombras.

No segundo parágrafo - "Vida eterna: visão de Deus" -, Gregório de Nissa se pergunta se é possível ver Deus e viver. A tradição bíblica diz que não, pois apresenta Moisés que, após ouvir Deus em uma visão, esconde o rosto para não morrer. Mas nosso teólogo diz que a esperança de vê-Lo não é uma fantasia, porque vimos o Seu Filho, o Enviado por Ele para reconduzir toda a humanidade: o Enviado do Pai o deu a conhecer. Segundo nosso autor, ver Deus significa encontrar os bens (vida sem fim, Reino sem fim,

de contestação ao empirismo lógico ficou conhecido como "nova filosofia da ciência", defendida por nomes como Thomas Kuhn, Stephen Toulmin, Paul Feyerabend, entre outros. Uma das características dessa nova filosofia científica é a definição de teorias, não mais como simples coleções de sentenças, mas como "totalidades estruturadas". Um dos sinônimos para as "totalidades estruturadas" é paradigmas. Cf. VIDEIRA, Antonio Augusto Passos, "Para que servem as definições?", em EL-HANI, Charbel Nino; VIDEIRA, Antonio Augusto Passos (org.). O que é vida?, o. c., p. 27. Para aprofundamento, cf.: KÜHN, Thomas S. The Structure of Scientific Revolutions, Chicago, University of Chicago Press, 1962. 
alegria contínua, verdadeira luz, glória intangível, perpétua exultação). Ver Deus é contemplar Deus, e só contempla Deus quem tem o coração puro algo que não é impossível, pois todos podemos ser puros.

Se ver Deus é contemplá-Lo, então todos e sempre podemos vê-Lo embora não possamos ver Deus através do intelecto, mas através de outros olhos. Gregório de Nissa nos adverte, então, que o objeto de nossa busca está além do nosso campo visível: contemplar é, assim, ver em mistério. O Deus inacessível a toda investida do conhecimento humano Se doa à criatura, mudando-lhe o coração e fazendo-a ver a si mesma. Quem vê Deus, vê a vida, Ele é princípio de vida e a Sua essência não pode ser fechada em conceitos humanos. Portanto, nessa segunda parte, o verbo-chave na teologia gregoriana é ver.

No terceiro parágrafo - "Vida eterna: nascimento e morte" -, quando reflete o Livro do Eclesiastes, Gregório de Nissa apresenta como elementos teológicos: nascer em tempo querido e morrer em tempo oportuno; a Palavra, que dá o verdadeiro conhecimento de Deus; a morte da condição humana que nos mergulha no nascimento para a vida eterna em Deus. Nosso teólogo admite não ser virtude nascer ou morrer, pois não estão em nosso poder esse nascer e morrer; mas liga, necessariamente, o morrer da condição humana com o nascimento para a vida eterna. Entretanto, o espírito humano, que busca em si mesmo a vida de eternidade, encontra-se fadigado: para Gregório de Nissa, o nascimento para a eterna visão de Deus e a morte da condição humana pertencem à mesma dinâmica, são correlatos, e escandem o ritmo da vida, inexoravelmente - sem morte, não há vida. A morte vem em tempo oportuno e, o parto e o nascimento para a vida eterna, em tempo querido.

Num primeiro plano da sua teologia, o nisseno diz que, "somos pais de nós mesmos" - ou seja, nos geramos a nós mesmos para a vida eterna. Num segundo plano, ele revela que esse processo - nascimento, vida, morte e parto para a vida eterna - formam em nós a imagem de Cristo, que se encarna, nasce, vive, morre e ressuscita. Cristo engloba e, ao mesmo tempo, transcende em Si o tempo, rompe com a finitude da temporalidade. Gregório de Nissa retoma a apresentação de São Paulo, para o qual morrer oportunamente é, diariamente, morrer para tudo aquilo que nos distancia da vida eterna. $\mathrm{O}$ efeito da morte oportuna é nascer num tempo querido. Assim, o verbo-chave para esse momento da teologia de Gregório é viver - a vida eterna, o tempo querido. Finalmente, percebemos o círculo metodológico da teologia de Gregório de Nissa, através dos verbos-chaves: ouvir, ver e viver. 
2.2. Primeira aproximação: uma nova linguagem e uma nova abordagem cientificas

Como pudemos perceber, a linguagem de Gregório de Nissa é, essencialmente, teológica e simbólica. A priori, não percebemos como essa linguagem se aproximaria das ciências da vida; contudo, uma possibilidade se vislumbra, a partir de uma nova linguagem e de uma nova abordagem científica que têm surgido nas últimas décadas.

Principalmente na área da biologia, essa nova linguagem está voltada para o que atualmente chamamos de sistemas da vida ${ }^{33}$, expressão identificada com vários sinônimos, como teoria dos sistemas dinâmicos ou da complexidade, dinâmica não-linear ou de rede, entre outros. É, em nossos dias, a linguagem preferida para autores como Fritjof Capra, pois ela oferece uma visão unificada entre mente, matéria e vida.

Houve um paradigma científico, surgido a partir da física dos séculos XVI-XVII, que vigeu durante séculos e que agora mostra sua insuficiência para explicar a realidade. Esse paradigma apresentava várias idéias e valores, que trouxeram conseqüências sérias: a visão do universo era a de um sistema mecânico e, a do corpo humano, como uma máquina ${ }^{34}$. Essa visão científica trouxe uma conseqüente visão cultural, como, por exemplo, a da vida em sociedade como pura competição, a crença em um ilimitado progresso material e tecnológico e a classificação da mulher como inferior ao homem, entre outras características ${ }^{35}$.

Todas essas suposições têm sido questionadas pelos novos paradigmas científicos $^{36}$. Para Fritjof Capra e outros autores, tal mudança de paradigma

${ }^{33}$ Cf. CAPRA, Fritjof, A Teia da Vida, São Paulo, Editora Cultrix, 2002, p. 19-20. Cf. JUDSON, Horace Freeland, The Eighth Day of Creatio,. New York, Simon \& Schuster, 1979, p. 209; 220.

${ }^{34}$ Tal teoria nasceu no século XVII, quando Galileu Galilei e Isaac Newton desenvolveram as bases da mecânica, que estuda o movimento de corpos materiais no espaço. A física dessa época explicava o mecanismo do "relógio-Universo" através da Lei de Gravitação Universal: o que acontecia num ponto do Universo acontecia da mesma forma em um outro ponto. Tudo parecia obedecer a uma ordem inabalável de causas e efeitos, perfeitamente agendáveis e previsíveis. Tudo era explicado pela ciência e seu método experimental. O método experimental científico era a lei de ordem e de progresso, transposta, então, para as demais leis no funcionamento total da sociedade. Nota das Autoras. Muitos autores atestam essa visão mecanicista, como, por exemplo: FEYNMAN, R. P., Física em seis lições, Editora Ediouro, 2004.

${ }^{35}$ Cf. CAPRA, Fritjof, o. c., p. 25.

${ }^{36}$ Paradigma, aqui, é empregado para definir a representação dos modelos a serem seguidos é uma teoria matriz, que origina o estudo de um campo científico; são métodos e valores concebidos como modelos. Cf. ASSMANN, Hugo, "Paradigmas ou cenários epistemológicos complexos?”. In: VV.AA., Teologia aberta ao futuro, Editora Soter/Edições Loyola, 1997, p. 41-66. Historicamente, é na fisica que encontramos o modelo fundamental 
nas ciências implica uma mudança metodológica: ao invés de partirmos da física - que explica experimentalmente a realidade - devemos partir das ciências da vida (biologia, biogênese, varredura do cérebro, arqueologia, estudo dos fósseis, entre outras) $)^{37}$.

Tal mudança de método implica numa nova visão que enfatiza o todo, chamada de pensamento sistêmico, holístico, organísmico ou ecológico ${ }^{38}$. Esta forma de pensamento é muito antiga, embora tenha ficado esquecida no mundo ocidental nos últimos séculos ${ }^{39}$. Os biólogos pioneiros da retomada do pensamento sistêmico da década de 20 , sentiram seu pensamento enriquecido pela psicologia da Gestalt, pela nova ciência da ecologia ${ }^{40}$ e pela física quântica ${ }^{41}$. Na área da biologia, um dos primeiros biólogos a fazer essa

para a estruturação das teorias científicas, desde o século XIX, com as descobertas dos raios X, da eletricidade, do campo elétrico e do campo eletromagnético. Em 1900, Max Planck propôs que a luz e outras radiações eletromagnéticas (até então consideradas como ondas), comportavam-se também como pequenos feixes de energia - ou quanta - quando interagiam com a matéria: isso foi uma revolução na física, conhecida como a mecânica quântica. Essa descoberta deu-se logo após 1920, precedida pela Teoria da Relatividade Especial e pela Teoria da Relatividade Geral, ambas de Albert Einstein. Nota das Autoras. Para aprofundamento, cf. LOPES, José Leite, A Estrutura Quântica da Matéria. Do átomo pré-socrático às particulas elementares, Editora UFRJ, $2005^{3}$.

${ }^{37}$ Cf. CAPRA, Fritjof, o. c., p. 29. Cf. EL-HANI, Charbel Nino; VIDEIRA, Antonio Augusto Passos (org.), O que é vida?, o. c., p. 7.

${ }^{38}$ Cf. ibidem, p. $33 ; 39-40$.

${ }^{39}$ As concepções de Aristóteles, por exemplo, apesar de sua lógica formal, eram unificadoras; entretanto, a unicidade do pensamento aristotélico foi abandonada e sua lógica formal foi acentuada nos séculos XVI e XVII. Cf. KÜHN, Thomas S, o. c. No final do século XVIII e no século XIX, o movimento romântico ofereceu uma forte oposição ao paradigma cartesiano mecanicista, retornando à tradição aristotélica. Cf. DEVALL, Bill; SESSIONS, George. Deep Ecology. Salt Lake City, Utah. Peregrine Smith. 1985. A importância da organicidade também está presente na filosofia de Immanuel Kant - um dos maiores filósofos modernos. Cf. MERCHANT, Carolyn (org.). Ecology. Atlantic Highlands. Humanities Press. 1994. Cf. EISLER, Riane. The Chalice and the Blade. San Francisco. Harper \& Row. 1987. Na segunda metade do século XIX, o mecanicismo ressurgiu, principalmente por época do aperfeiçoamento do microscópio, trazendo notáveis avanços em biologia. Cf. MACY, Joanna. World As Lover, World As Self. Berkeley, Califórnia. Parallax Press. 1991. A teoria das células, a embriologia e a microbiologia estabeleceram o pensamento mecanicista na biologia; contudo, no início do século XX, a concepção de organização foi, aos poucos, substituindo a visão meramente fisiológica dos organismos vivos. Cf. HARAWAY, Donna Jeanne. Crystals, Fabrics and Fields: Metaphors of Organicism in Twentieth-Century Developmental Biology. New Haven. Yale University Press. 1976. Cf. LILIENFELD, Robert. The Rise of Systems Thory, New York, John Wiley, 1978. Cf. CAPRA, Fritjof., o. c., p. 33-39.

${ }^{40}$ Muitos autores estão trabalhando nessa referência ecológica, como, por exemplo: BOFF, Leonardo, Ecologia. Grito da Terra - Grito dos pobres, São Paulo, Editora Ática, 1995.

${ }^{41}$ Para aprofundamento sobre a física quântica, cf. ZOHAR, Dannah; MARSHALL, Ian. QS. $O$ " $Q$ " que faz a diferenço, Rio de Janeiro, Editora Record, 2002. A quântica, atualmente, é um aspecto quase fundamental em várias áreas científicas: cf. BUNGE, Annik Vivier, Intro- 
mudança foi Ross Harrison, que, gradualmente, substituiu, na análise dos organismos vivos, a velha noção de função (= visão mecanicista) por organização, que possui dois aspectos importantes: a configuração e a relação entre as diversas partes que compõem os organismos vivos, tudo o que tem vida ${ }^{42}$.

A palavra sistema deriva do grego synhistanai (= colocar junto) e o bioquímico Lawrence Henderson a usou para denotar tanto os organismos vivos quanto os sistemas sociais, formando relações em um todo integrado. O biólogo Joseph Woodger e muitos outros enfatizaram que uma propriedade que se destaca em toda a vida existente é sua tendência para formar estruturas multiniveladas de sistemas dentro de sistemas: as estruturas básicas dos organismos vivos se encontram dentro de outras estruturas, que, por sua vez, se relacionam com outras estruturas maiores - ou seja: essas diversas estruturas interligadas formam o que chamamos hoje de sistema integrado ${ }^{43}$.

\section{Concluindo}

Notamos, aqui, uma primeira possibilidade de aproximação entre a teologia de Gregório de Nissa e os novos paradigmas científicos: a linguagem. Tanto na teologia de Gregório de Nissa quanto nos novos paradigmas científicos, notamos uma busca pela integração. O método de Gregório de Nissa é integrado e determina sua linguagem: no texto analisado, por exemplo, ele relaciona a morte da condição humana com o nascimento para a vida eterna, relaciona contemplação com pureza de coração, entre outras imagens.

O método de Gregório de Nissa, portanto, une conhecimento e fé, integrando os saberes acessíveis em sua época - fé e razão - com sua teologia e mística - algo inédito para seu tempo ${ }^{44}$. Muitos desses saberes de sua época ele retira da filosofia platônica, integrando-os com sua teologia e mística. Seguindo o caminho da integração, também o atual método das ciências da vida busca uma integração entre os diversos saberes para explicar o fenômeno da vida.

dução à Química Quântic,. Editora Edgard Blücher Ltda, 1977. Muitas coisas que consideramos racionais são, hoje, invalidadas pela física quântica: cf. ZEILINGER, Anton, $A$ face oculta da natureza. O novo mundo da física quântica, Editora Globo, 2005. Toda essa pesquisa e outras estão implicando uma nova linguagem científica.

${ }_{42}$ Cf. CAPRA, Fritjof, o. c., p. 40.

${ }^{43}$ Dentro dessa nova visão, não podemos analisar um organismo vivo ou uma parte desse organismo, sem analisarmos, conjuntamente, outros sistemas e outras partes do mesmo organismo. 


\subsection{Segunda aproximação: a vida como mistério ${ }^{45}$}

A origem da vida ocupa um lugar especial na vasta lista das questões em aberto nas atuais ciências. Duas idéias recentes têm despertado bastante discussão: a primeira (baseada na presença de compostos orgânicos em asteróides) é que a vida veio do espaço; a segunda, é que ela surgiu nas profundezas dos oceanos primitivos. De qualquer forma, segundo as ciências, a vida em nosso planeta originou-se na água e, hoje, onde quer que haja água, quase sempre há vida ${ }^{46}$. No deserto, por exemplo, há plantas que percorrem um ciclo inteiro de vida (semente, flor, semente) logo depois de uma pancada de chuva; na floresta, a água coletada nas folhas de uma planta tropical forma um microcosmo, no qual miríades de pequenos organismos nascem, se reproduzem e morrem... Três quartos da superfície da Terra estão cobertos de água; a água constitui de $50 \%$ a $95 \%$ do peso de qualquer ser vivo em atividade... Sem a água, é bem provável que a vida não tivesse existido.

Assim, a água - elemento simples, comum e, ao mesmo tempo, extraordinário - abrigou o surgimento da vida em nosso planeta. Mas a vida, para as ciências, permanece um mistério: segundo os biólogos, a matéria viva é extremamente complexa, resultado de reações químicas, combinações moleculares e flutuações estatísticas muito improváveis - ou seja: a vida é um processo raríssimo ${ }^{47}$ ! Por outro lado, toda a matéria conhecida possui uma "montagem" surpreendentemente simples, a partir de sua constituição de prótons, nêutrons e elétrons - cerca de 90 tipos de átomos são necessários para a formação de todas as moléculas encontradas no Universo ${ }^{48}$ ! É a partir da simplicidade dessas estruturas básicas que se forma a complexidade que nos rodeia. Em uma molécula - DNA - encontra-se, ao mesmo tempo, toda a variedade da espécie humana, assim como sua homogeneidade!

\footnotetext{
${ }^{45}$ Para as ciências, "mistério" é sinônimo de enigma; para a teologia, Mistério é algo dado, revelado, mas que nós ainda não conseguimos abarcar completamente. Entretanto, existe uma característica comum a esses dois significados: ambos se abrem ao novo, ao que irá explicitar o que agora se manifesta na obscuridade e limitação. A diferença mais profunda encontra-se no fato de que a teologia, porque aberta à Revelação de Deus, conhece de antemão e atesta com veracidade aquilo que hoje ainda não apreendemos perfeitamente.

${ }^{46}$ Cf. CURTIS, Helena, Biologia, Editora Guanabara Koogan S. A., Rio de Janeiro, $1977^{2}$, p. $40-47$.

${ }^{47}$ Cf. CAPRA, F., O ponto de mutação. A ciência, a sociedade e a cultura emergente, Editora Cultrix, 2003, p. 259s. Cf. VIDEIRA, Antonio Augusto Passos, "Para que servem as definições?”, em EL-HANI, Charbel Niño; VIDEIRA, Antonio Augusto Passos (org.), o. c., p. 2526. Cf. EMMECHE, Claus; EL-HANI,Charbel Niño "Definindo vida", em ibidem, p. 32; 3435 .

${ }^{48}$ Cf. VIEYRA, Adalberto; SOUZA-BARROS, Fernando, "Teorias da Origem da Vida no Século XX", em ibidem., p. 74.
} 
Muitas vezes, o que as ciências dizem ser "enigma", ao tratarem da origem do Universo e da vida, nós, teólogas e teólogos, chamamos de providência do Criador. Deus criou do nada, Ele é o autor da vida e do Universo e proveu o cosmo para que a vida fosse possível. Os físicos céticos acerca da criação de tudo por Deus argumentam que tudo veio do acaso; mas como o acaso pôde gerar tudo e gerar contra toda a possibilidade de vida? As pesquisas acerca do surgimento do Universo têm nos impactado, por nos mostrar uma série de "coincidências" que, pela lógica, não aconteceriam.

Por exemplo: a expansão do universo após a explosão do Big Bang dependeu, essencialmente, da quantidade total de massa e energia que o universo apresentava e também da força da constante gravitacional, em profunda sintonia ${ }^{49}$. Ou seja: se tivesse existido uma mínima desproporção entre esses elementos - massa, energia e constante gravitacional, o Universo não se expandiria e, portanto, nada existiria.

\section{Concluindo}

A teologia de Gregório de Nissa nos apresenta Deus como mistério; no tópico acima, observamos que, para as ciências, o surgimento da vida em si desponta, também, como mistério. O que leva os organismos vivos a viverem? As ciências dizem que eles vivem e como vivem; mas, por que eles vivem?

Segundo o autor em estudo, a voz do amado chama a amada para a vida eterna; identificamos, acima, que Deus provocou o Big Bang, chamando tudo à vida, com sua voz e Palavra: "Faça-se..." e tudo foi feito (cf. Gn 1). Na reflexão de Gregório de Nissa, só a voz do amado não basta: a amada reconhece a voz do amado que a chama para a vida eterna porque o amado a chama pelo nome. Assim, o nome dá identidade à amada, a tira do anonimato, a faz reconhecer a vida presente nela. $\mathrm{O}$ nome dá identidade e unicidade à amada. Por sua vez, o tópico acima acerca das ciências da vida aponta para a existência de uma realidade profunda: nenhuma célula de um organismo vivo é necessária e rigidamente igual à outra. Somos - os seres vivos - diferentes, únicos, nomeados, identificados, e assim o somos ao sermos chamados à vida.

Gregório de Nissa nos lembra que o encontro do amado com a amada, que a chama para a vida eterna, se dá ao meio-dia, hora em que o sol cai a pino e as sombras desaparecem. A luz, portanto, invade a amada, que bebe da fonte que jorra. Água viva e se alimenta da voz do amado. Nosso teólogo

${ }^{49}$ Cf. COLLINS, Francis S., A linguagem de Deus, São Paulo, Editora Gente, 2007², p. 79-81. 
aproxima, assim, a voz do amado à fonte de água viva - a vida eterna; também as ciências destacam o valor da água, sem a qual a vida não existiria em nosso planeta.

Gregório atesta um desejo de Deus presente no ser humano: a amada entra na vida eterna por causa da voz do amado. Ouvir, aqui, é auscultar: ouvir por dentro. "Voz" e "nome" enchem o vazio da existência humana corresponderiam, assim, ao desejo de vida eterna presente no humano. Nas ciências, vimos que a evolução é um chamado presente na matéria - é como se fosse a voz que Gregório associa ao amado. Somos chamados à evolução!

A evolução, então, é um dado indiscutível para as atuais ciências da vida. Entretanto, segundo o evolucionismo, a matéria evolui por ser "egoísta": para sobreviver, os genes fortes precisam sobrepujar os genes fracos. Ora, o ser humano não só evolui, como também é altruísta, se dedica a causas e pessoas que geralmente, vivem sem defesa e enfraquecidas. Aproximando-nos um pouco mais da linguagem da fé - que busca transcender o humano -, se doa e se entrega porque ama. Assim, essa não-lógica - o amor é mais forte que a própria evolução, pois aqueles que gastam sua vida em prol de um bem maior que si mesmos, desafiam a própria lei da matéria!

\subsection{Terceira aproximação: a realidade da evolução ${ }^{50}$}

Descobrimos uma evolução no pensamento e na concepção de vida para Gregório de Nissa. No primeiro artigo, ele parte da vida como um novo nascimento. Novo nascimento, para ele, é a Nova Geração. Esse novo nascimento cultiva um alto estilo de vida, de forma ascendente: através da geração do Batismo, alimentada pela Eucaristia, a pessoa atinge a maturidade humana e espiritual. O destino dessa Nova Família não é a morte, mas a vida eterna. Essa nova geração desfruta, assim, da vida em abundância. A ressurreição de Cristo traz, para essa Nova Geração, uma grande mudança no modo de viver a vida, agora baseada na relação. Portanto, o bispo nisseno revela o percurso e as etapas do caminho da pessoa humana em direção à Realidade do desejo, a qual aspira. Entendemos, aqui, a presença de evolução no pensamento teológico de Gregório de Nissa. Como podemos perceber, ao menos no método, Gregório de Nissa admite um processo dinâmico e ascendente, na pessoa humana em sua relação com o Criador.

Também as ciências da vida afirmam uma evolução - embora, em parte, distinta daquela apresentada por Gregório de Nissa. A evolução do universo, do nosso planeta e da própria vida é um fato verificado com suficiente

\footnotetext{
${ }^{50}$ Sobre o debate criação e evolução, cf., por exemplo, FREIRE-MAIA, Newton, Criação e evolução. Deus, o acaso e a necessidade, Vozes, 1986, passim.
} 
confiança $^{51}$. Notamos vários exemplos dessa evolução: a imprevisibilidade do clima, a grafia incorreta de um gene no processo da divisão celular, entre outros $^{52}$. A evolução é definida como a ligação genealógica entre todos os organismos terrestres, baseada em sua descendência de um ancestral comum, e a história de qualquer linhagem como um processo de descendência com modificações ${ }^{53}$.

Também nós, seres humanos - como tudo o que tem vida na natureza evoluímos. O Homo sapiens surgiu há cerca de 100 mil anos, enquanto toda a nossa linhagem humana talvez tenha surgido de seis a oito milhões de a$\operatorname{nos}^{54}$. O dado da evolução da matéria é, hoje, cientificamente incontestado: "na natureza, nada é criado, tudo se transforma". Essa máxima é do físico Antoine Laurent de Lavoisier quando, em 1789, formulou essa sua famosa Lei de Conservação da Massa ${ }^{55}$. A nosso ver, o que Lavoisier queria destacar é a segunda parte de sua máxima ("tudo se transforma"): a dinamicidade, o caráter de mudança presente em tudo o que é vivo.

Essa evolução de todo organismo vivo está presente, também, em nosso planeta-mãe, o planeta que acolheu a vida. A Terra não apenas funciona como um organismo vivo: ela o e é $^{56}$. Todos os seres que ela abriga são interdependentes: a concepção de auto-organização evidencia que a evolução acontece através de uma interação entre adaptação e criação ${ }^{57}$. O processo

\footnotetext{
${ }^{51}$ A teoria evolucionista é elaborada a partir de três aspectos principais: a relação ancestral entre os organismos, o aparecimento de novas características em uma linhagem e o mecanismo que faz com que algumas características persistam enquanto outras perecem. A maioria dos biólogos acredita que toda a vida na Terra descenda de um ancestral comum, chamado de LUCA (Last Universal Common Ancestor), devido ao fato de que os organismos vivos apresentam características básicas semelhantes. Nota das Autoras. Para maior aprofundamento, cf. COLLINS, Francis S., o.c. Cf. FOLEY, Robert, Apenas mais uma espécie única, Edusp (Editora da Universidade de São Paulo), 1993.

${ }_{52}^{52}$ Cf. COLLINS, Francis S., o. c., p. 53.

${ }^{53}$ GOULD, Stephen Jay, em ZIMMER, Carl, o. c., p. 9. Sobre atuais descobertas acerca da origem da vida, cf.: DELSEMME, Armand. Our Cosmic Origins, Cambridge University Press, 1998. Sobre o ancestral comum, do qual todos os seres vivos descenderiam, cf.: VIEYRA, Adalberto; SOUZA-BARROS, Fernando, "Teorias da Origem da Vida no Século XX", em EL-HANI, Charbel Nino; VIDEIRA, Antonio Augusto Passos (org.), O que é vida?, o. c., p. 72-73.

${ }^{54}$ Para aprofundamento, cf.: CHARDIN, Teilhard, La Place de l'Homme dans la Nature, Éditions du Seuil, Paris, 1956. Cf. PIÉRON, Henri, L'Homme, rien que l'Homme, Presses Universitaires de France, 1967. Cf. FOLEY, Robert, o. c. Cf. ATLAN, Henri, Entre o cristal e a fumaça, Jorge Zahar Editor, 1992.

${ }^{55}$ Cf. COLLINS, Francis S., o. c., p. 10 s.

${ }^{56}$ Cf. CAPRA, Fritjof, O Ponto de Mutação, o. c., p. 278.

${ }^{57}$ Os organismos vivos são complexos e altamente organizados. Os organismos vivos também são compostos de átomos e moléculas - como os organismos não-vivos -, mas são organizados de forma mais complexa. Dizemos que a célula dos organismos vivos é auto-organizada
} 
não é linear, seqüencial, mas inter-relacional. Não há evolução, mas coevolução de microcosmo e de macrocosmo: dois aspectos complementares do mesmo processo evolutivo.

\section{Concluindo}

Do tópico acima analisado, destacamos duas características: a presença de uma evolução no pensamento de Gregório de Nissa e a presença da teoria evolucionista da matéria comprovada pelas ciências da vida. Nós descobrimos, nas reflexões de Gregório de Nissa, uma evolução ascendente e processual: segundo ele, nascer para a vida eterna é participar de uma Nova Geração, que se inicia com o Batismo e é alimentada pela Eucaristia. Ter a vida eterna é amadurecer - humana e espiritualmente.

Nas ciências, essa evolução é processual também, mas não ascendente: a idéia de um processo linear e de ascensão no processo evolutivo tem sido abandonada pelas recentes descobertas feitas pelas ciências da vida. Com efeito, até algumas décadas atrás, pensava-se a evolução como a culminância de perfeição; isto é, um organismo evoluído era interpretado como um cume alcançado pelo processo evolutivo, resultado de múltiplas adaptações ao ambiente - o que se pensava era que não somente evoluía aquele ser vivo que alcançara a "perfeição" até o presente momento, como aquele "mais forte". Ora, na cadeia de seres vivos que habitam nosso planeta, o ser mais "perfeito" e mais "forte" seríamos nós, seres humanos.

Atualmente, esse pensamento tem sido questionado pelas ciências da vida. Primeiramente, a idéia de evolução ascendente. Segundo este tipo de pensamento evolucionista, a nossa era humana - homo sapiens - seria o resultado atual final de um ciclo evolutivo a partir de ancestrais nossos, australopitecos e hominídeos. Entretanto, recentes descobertas de fósseis feitas pela arqueologia comprovam que alguns de nossos ancestrais conviveram na mesma época que o homo sapiens ${ }^{58}$.

porque, entre outros motivos, ela possui uma membrana que a envolve e regula a passagem de
material para dentro e para fora, diferindo a célula do seu meio-ambiente. Neste sentido, as
células são unidades independentes, autônomas. Entretanto, na medida em que as células
necessitam dos materiais do ambiente ao seu redor para viver, ela é dependente do meio am-
biente. Cf. CURTIS, Helena, o. c., pp. $23-24 ; 77 ; 92-94$.
58 No século XIX, a palavra "evolução" era identificada como melhoria. Aliás, antes de
Darwin, se interpretava igualmente as mudanças biológicas como uma melhoria. No entanto,
a seleção natural não implica em alguma forma de melhoria "absoluta", rumo a uma perfeição
ideal, mas é meramente o resultado do acúmulo de características hereditárias que ao longo do
tempo, em dado momento da história das linhagens, foram relativamente vantajosas aos seus
portadores em seus respectivos ambientes. Assim, um ser vivo (ou fossilizado) "evoluído" 
Assim, a partir dessas descobertas, entendemos que nós, seres humanos, não estamos acima dos demais seres vivos - como se fôssemos superiores aos demais por sermos mais evoluídos. Portanto, para as ciências atuais, evolução não é sinônimo de perfeição, de melhoria moral e ética (no sentido de ser melhor), mas, para as ciências, evolução é sinônimo de mudança ou transformação. Assim, na concepção das ciências, quando mudamos, evoluímos. Essa descoberta quebrou o antigo paradigma cultural, que afirmava o ser humano como senhor e dono da criação, acima dela e, não, parte dela.

Quem destaca a importância da transformação da e na matéria, como vimos anteriormente, é Antoine Lavoisier. Aqui, neste artigo, interpretamos que a máxima de Lavoisier - "na natureza, nada se cria, tudo se transforma" pode se aproximar da teologia nissena. Para fundamentar tal afirmação, não enfatizamos a primeira assertiva de Lavoisier ("nada foi criado"), mas a segunda ("tudo se transforma"). Na nossa interpretação, a primeira afirmação não se aproxima do pensamento de Gregório de Nissa, mas a segunda sim. Ora, se tudo se transforma, a morte da matéria entra como componente necessário desta transformação. Para Gregório, a morte da condição humana nos abre para a dimensão eterna da vida. Ele interpreta a afirmação do Eclesiastes - há um tempo de dar a luz e um tempo de morrer (Ecle 3,2) - como uma necessária interdependência entre a morte da condição humana e o nascimento para a eternidade.

Também as ciências atuais estudam a realidade da morte da matéria. Segundo a biogênese, só houve variedade e abundância de vida na Terra quando a matéria morreu - princípio que ainda continua acontecendo ${ }^{59}$. Ou seja: segundo as ciências da vida, somente quando um organismo vivo morreu, a natureza pôde evoluir, se adaptar, realizar transformações - numa palavra, criar! É neste sentido que afirmamos, anteriormente, que somos pais de nós mesmos, que nos geramos.

não é aquele que é "melhor" ou "superior" (no sentido moral da palavra), mas aquele ser que sofreu uma mutação ou, no mínimo, uma transformação em função da adaptação a um novo ambiente de vida, ou aquele que acumulou em seus genes informações acerca de melhores características que se ajustariam a novos ou inóspitos ambientes. "Ser evoluído", portanto, é sinônimo de "ser melhor adaptado" e não de "ser melhor".

${ }^{59}$ Segundo as ciências da vida, as bactérias hoje são as mesmas que povoaram a Terra há bilhões de anos, ramificadas em inúmeros organismos! É, portanto, uma espécie de vida sem morte. Essa 'vida sem morte' foi a única a existir nos primeiros dois terços da história da evolução, segundo registram os fósseis encontrados. Somente após a morte dos organismos vivos, derivados - ou evoluídos - das bactérias, é que a vida começou a se manifestar numa variedade e numa intensidade intensas. O período anterior - sem envelhecimento nem morte foi um período de vida sim, mas uma vida sem variedade e sem nenhuma forma de vida superior! Cf. CAPRA, F., O ponto de mutação, o. c.,. p. 264. 
Para Gregório de Nissa, há uma interdependência entre a morte da condição humana e o nascimento para a eternidade. Dentro desta concepção, o nascimento para a eterna visão de Deus e a morte da matéria são marcas essenciais da criação, pois sem morte não há vida. Ele compreende a criaturidade e o nascimento para a eternidade como "o tempo querido" e, a morte da condição humana e terrena, "um tempo oportuno". Ora, a nosso ver, o "tempo querido" gregoriano é a evolução da nossa criaturidade, em direção à vida eterna. É “oportuno" morrer, pois "queremos" viver - ou seja: evoluir, nos transformar. Para as ciências da vida, a natureza passa por estágios de evolução que a fazem criar, através dessas sucessivas transformações. É transformando que a natureza cria.

Para a reflexão teológica, a vida não se acaba com a morte da matéria essa contribuição é inédita e específica da Tradição cristã. Como vimos na segunda parte deste artigo, somos criaturas e, portanto, mortais. Mas a vida, para a Tradição cristã, é, em última instância, salvação. Vida eterna - ou eternidade - para a fé cristã, é o desfecho de todo bem salvífico, uma herança que não perece: o Desejo definitivo de Deus. Na linguagem teológica, seria o cume de nossa "evolução", que, assim, abarcaria não somente a vida de nossa matéria, mas a vida de todas as nossas dimensões humanas. Assim, a nosso ver, neste sentido, a visão teológica de evolução se distancia do conceito científico de evolução, pois, para as ciências da vida, a vida se acaba com a morte total da matéria - o que não morre é a energia que, para as ciências, é um dos conceitos mais importantes ${ }^{60}$.

Nossa atenção se dirige agora para a primeira assertiva da máxima de Lavoisier - "na natureza, nada se cria". Parece-nos que Lavoisier entende, aqui, a criação não como algo pronto, dado, acabado: a natureza está aberta à evolução e a traz como sua marca essencial. Essa descoberta de Lavoisier questiona a nossa idéia teológica de criação. Quando afirmamos teologicamente a criação, geralmente somos levados a compreendê-la de forma mágica, como algo já pronto. Para a ciência, algo "pronto" não é algo "criado". É

\footnotetext{
${ }^{60}$ Também na Tradição Católica, encontramos a palavra "energia" com este sentido (vigor, movimento,...), como, por exemplo, no discurso de SS. o Papa Paulo VI, em 1965, dirigindose aos fiéis sobre a publicação da Constituição Dogmática do Concílio Vaticano II Lúmen gentium: Este olhar que se estende para adiante sobre o futuro, olha distante, e o seu horizonte está envolto por uma névoa luminosa, que não deixa ver nas suas peculiaridades, mas o faz entrever em imagens, em sinais, em indícios que bastam para confirmar a direção do caminho empreendido e imprimir ao movimento da Igreja uma especial energia, uma aceleração segura: é a Esperança final: é a certeza do futuro encontro com Cristo glorioso. Cf. AA.VV. La Constituzione Dogmática sulla Chiesa, Torino-Leumann, 1967, p. 871-872. Apud BOFF, Lina. "Índole escatológica da igreja peregrinante", em Atualidade Teológica. Ano VII, 2003, fasc. 13 , p. 9-31.
} 
uma visão que nos ajuda a repensar nossos conceitos teológicos acerca da criação de Deus. Pois, segundo o pensamento científico atual, se Deus criasse "acabado", não criaria. A evolução são etapas necessárias para a criação!

Não é Deus que faz a evolução - de fora para dentro da matéria; mas Deus cria a matéria com a essência da evolução nela ${ }^{61}$. Teologicamente, afirmamos que tudo o que é criado por Deus é criado com finalidade; ora, depois da reflexão acima, entendemos que a finalidade da matéria é evoluir. Assim, cabe à teologia dizer porque Deus cria assim e não de forma "acabada" - tarefa da qual este artigo não dá conta.

Como vimos ao longo dessa aproximação, tudo o que tem vida não somente evolui, mas evolui conjuntamente - teologicamente falando, em comunhão. Encontramos, aqui, outro ponto de proximidade com o pensamento nisseno, quando ele afirma que "evoluir" é alcançar a vida eterna uma vida eterna que não esconde o trabalho árduo da alma em buscá-la. Um trabalho penoso e difícil, como um parto. Neste parto dolorido, segundo Gregório, nós somos, de certo modo, "pais de nós mesmos". Ou seja: nós nos "geramos" (= evoluímos) para a vida, e vida eterna! Ora, segundo as atuais ciências da vida, esse "parto" não pode ser solitário, pois evoluímos conjuntamente! Somos co-responsáveis uns pelos outros! Realmente, para Gregório, esse "parto" gera a própria salvação e, segundo a teologia cristã, só nos salvamos juntos, em comunhão!

Ao lado das questões que envolvem a teoria evolucionista, outras perguntas ainda são levantadas, para as quais as ciências da vida não possuem uma resposta. Por exemplo: persiste no ser humano - mesmo com toda nossa evolução e complexidade - um desejo de algo maior que nós. Este desejo que muitos não conseguem identificar ou nomear - para nós é o desejo de Deus. Ele não parece ser um desejo isolado deste ou daquele indivíduo ou de determinado grupo humano, pelo contrário: o anseio pelo sagrado manifestase, em quase todas as culturas, como um aspecto universal e enigmático da experiência humana ${ }^{62}$. É a dimensão de transcendência presente no ser humano: somos seres finitos que almejamos o infinito; é uma busca pelo Eterno, que ultrapassa a dimensão da materialidade. Esta dimensão a ciência ainda não consegue explicar.

Outro importante desafio às ciências da vida é a presença do altruísmo na espécie humana. Para a teologia, o altruísmo é uma virtude, uma atitude, uma ética. Para as ciências da vida, o altruísmo é um mistério. Ele pode levar os seres humanos a realizar sacrifícios que até poderão trazer sofrimento pessoal, ferimento ou morte, sem nenhuma garantia de retorno ou benefício.

${ }^{61}$ Cf. QUEIRUGA, André T., Fim do cristianismo pré-moderno, p. 97.

${ }^{62}$ Cf. COLINS, Francis S., o. c.,, p. 43-47. 
Ora, o evolucionismo apregoa exatamente o contrário: a seleção natural é produzida pelo impulso que os genes "egoístas" do indivíduo possuem de se perpetuar ${ }^{63}$. Como explicar cientificamente o sentimento de doação existente nas pessoas humanas - mártires, líderes de causas humanitárias, entre outros - doação que é maior que sua tendência genética de se proteger e se perpetuar? É uma pergunta ainda sem resposta pronta por parte das ciências, mas que a teologia descobre na Revelação de Deus. Uma descoberta que, aliás, Gregório de Nissa nos ajuda a compreender.

\subsection{Quarta aproximação: sem morte não há a vida}

Para Gregório de Nissa, o "morrer" não é o morrer físico, biológico; entretanto, ele admite o morrer físico para que haja o nascimento para a vida eterna $^{64}$. Segundo nosso teólogo, o nascimento para a eterna visão de Deus e a morte da condição humana são uma dinâmica que "escandem" o ritmo da vida, inexoravelmente: estes dois tempos tocam fortemente a vida do ser humano e de toda a criação, pois sem morte não há vida.

A morte também é fonte de pesquisa e de interesse para as ciências da vida. Aliás, segundo elas, algo em nós está sempre morrendo e nascendo ${ }^{65}$. O pâncreas substitui a maioria de suas células em 24 horas; o revestimento do estômago, em três dias; os leucócitos, em 10; $98 \%$ da proteína do cérebro são refeitas em menos de um mês... Planárias, pólipos e estrelas-do-mar se regeneram quase inteiramente a partir de um fragmento; lagartos, salamandras, caranguejos, lagostas e muitos insetos são capazes de renovar um órgão ou membro perdido; animais superiores renovam tecidos e curam ferimentos...

Incrivelmente, substituímos todas as nossas células (exceto as do cérebro), num prazo de poucos anos e, no entanto, não temos dificuldade em reconhecer nossos amigos, mesmo depois de longos períodos de separação! Mas os organismos vivos não vivem para sempre: sucumbem por exaustão!

\footnotetext{
${ }^{63}$ Cf. ibidem, p. 33-35.

${ }^{64} \mathrm{O}$ "morrer" de Gregório é o que se dá em momento oportuno para um nascimento que se dá em tempo querido. Em seu Diálogo com Macrina, ele se refere aos elementos que constituem o corpo humano e que, ao sermos introduzidos na plenitude da vida que é a vida eterna, estes elementos encontram sua fonte em Deus, de onde se originaram. Macrina conclui afirmando que como um ser divino existe no cosmo, assim a alma existe no corpo, pois tudo o que é matéria pressupõe uma realidade espiritual. Fundamenta-se na autoridade da Sagrada Escritura quando cita Gn 1,26: o ser humano - homem e mulher - são seres humanos criados, enquanto Deus é o Criador. Cf. "Saggio introdutivo", Sull Anima e la Resurezione, o. c, p. 55458.

${ }^{65}$ Cf. CAPRA, Fritjof., O Ponto de Mutação, o. c., p. 264s.
} 
Para sobreviver, as espécies não substituem partes, mas o organismo todo aliás, por isto nos reproduzimos! Quando nos reproduzimos, não reproduzimos um pedaço de nós, mas todo o nosso organismo. Mais uma vez, aparece aqui a importância do todo sobre as partes.

Nosso organismo gera coisas vivas a partir da morte de outras estruturas. É, de certa forma, a morte gerando vida. Quase todos os seres vivos que nos cercam renovam-se o tempo todo - tudo à nossa volta morre o tempo todo! Mas, para cada organismo que morre, um outro nasce! Portanto, para a ciência, a morte não é o oposto da vida, mas um aspecto essencial dela!

\section{Concluindo}

Vimos, assim, nessa aproximação, que também a morte - como a vida - é motivo de muitas pesquisas, tanto na teologia gregoriana quanto nas ciências da vida. Isto acontece porque a morte está sempre ao lado da vida, é sua companheira. Vimos que os seres vivos morrem e renascem o tempo todo ou seja: são pequenas mortes e pequenos renascimentos acontecendo o tempo todo dentro dos organismos vivos.

Podemos interpretar essa forma da vida e da morte irem acontecendo nos organismos vivos como uma preparação para nossa "grande morte" - ou morte total da matéria viva. Ou seja: ao nosso ver, a matéria viva, com suas pequenas mortes seqüenciais, vai nos ensinando a morrer de vez - e, por que não, a evoluir, o que, numa linguagem teológico-gregoriana, significa nascer para a vida eterna. A morte - "tempo oportuno" - acontece em função do nascimento para a vida eterna - "tempo querido".

Ao longo da explanação anterior, vimos que nosso cérebro humano trabalha articuladamente: pensamos numa pessoa querida, e o cérebro aciona, instantânea e concomitantemente, várias áreas cerebrais que compõem a imagem dessa pessoa, uma cena especial em que essa pessoa esteja presente e as emoções de saudade em forma de lágrimas. É tudo acionado e produzido conjuntamente pelo cérebro. Mas o cérebro não sabe que essa pessoa se encontra longe ou no passado; para ele, a mensagem que lhe enviamos está acontecendo - ou seja: o tempo do nosso cérebro é sempre o tempo presente, um tempo que não tem começo nem fim. É o que chamamos de "tempo quântico". Ora, podemos afirmar que, para a teologia de Gregório de Nissa, esse "tempo sempre presente" é a eternidade presente em nós, que independe do tempo cronológico, marcado pela sucessão de dias. Para ele, eternidade não é sinônimo de imortalidade. Encontramos, portanto, aqui, mais uma proximidade entre Gregório de Nissa e as ciências da vida. 


\section{Conclusão final}

Ao final deste trabalho, esperamos ter alcançado o nosso objetivo inicial, mesmo que de forma limitada. Partimos da teologia de Gregório de Nissa acerca da vida eterna e buscamos relacionar os elementos desta teologia com algumas das atuais descobertas das ciências da vida. Percebemos que, em alguns momentos, essa aproximação foi possível, e, em outros, não.

Sentimos que a experiência feita por nós foi gratificante. Acreditamos que o diálogo interdisciplinar entre teologia e ciências da vida é possível e urgente: o que precisamos, no mundo acadêmico, é abrir um debate sobre a questão e chamar a atenção para a necessidade de tal diálogo, buscando contribuir cada vez mais com a missão da teologia e ensaiar práticas de aproximações entre os campos epistemológicos.

Gregório de Nissa enfrenta, em forma de diálogo, um dos temas cruciais de seu tempo, que foi a relação entre Platonismo e Cristianismo: ele busca conciliar a doutrina platônica da imortalidade da alma com a doutrina cristã da ressurreição do corpo. Dá início assim, ao processo de assimilação das duas doutrinas que mais tarde se torna verdade da fé cristã no Tratado de Escatologia.

No aspecto da ciência, vimos, nesse artigo que, nos últimos quinhentos anos, aconteceram profundas transformações, alterando nossa compreensão da natureza da matéria e da estrutura do universo. Alguns cientistas acreditam, inclusive, que mais revisões ainda estão por vir em um futuro próximo.

Nesse necessário diálogo interdisciplinar, a teologia abre-se para colocar-se a serviço, guardando a sua identidade de sempre falar da essência da fé. Tentativas têm sido encetadas. Muitos autores-as têm analisado a relação entre fé e ciência, ou entre religião e ciência, ou entre teologia e ciência - dos quais este artigo não dá conta.

Podemos fazer interdisciplinaridade se respeitarmos ambos os campos: o da teologia e o das ciências, cada um em sua singularidade. O domínio da ciência está em explorar a natureza, não a realidade de Deus: o mundo espiritual é um campo que não é possível esquadrinhar com os instrumentos, a tecnologia e a linguagem das ciências. Tanto uma perspectiva - a científica quanto à outra - a teológica - podem coexistir, enriquecendo e iluminando a experiência humana. A ciência, atualmente, é a forma confiável para entender a natureza; entretanto, ela não consegue responder a questões fundamentais, como: por que o universo existe?, Qual o sentido da existência humana?, O que acontece após a morte?, Por que existimos?.

Com Gregório de Nissa, concluímos: vida eterna para ele é a voz que chama pelo nome; é ver Deus pela pureza de coração; e é "nascer em tempo 
querido e morrer em tempo oportuno". Nascer para a visão beatífica do Deus Comunidade de amor e morrer para tudo aquilo que pode nos afastar d'Ele. O nascimento e a morte são uma dinâmica que "escandem" a vida, inexoravelmente. É preciso compreender, portanto, que viver a eternidade de Deus, é realizar a plena identidade que traz seu nome, gozar da visão beatífica na transcendência da temporalidade humana e nascer para a plenitude do Cristo ressuscitado, o Vivente.

\section{Resumée}

La concepción de vie eternelle dnas Grégoire de Nice est extraite des livres de la Sainte Écriture. Pour lui vie eternelle ex une voix qui appéle par le non du Cantique des Catiques; c'est voir de Dieu par la pureté de coeur et continuer, em vivant, d'après son ouevre sur la vie de Moïse; et enfin, vie eternelle est naissence et mort, conception extraite de l'Ecclesiastique. Avecla capacité d'um grand maitre de la mystique et d'une recherche théologique du sens plein de la vie, Grégoire elabore sés commentaires em utilisant des métaphores et dês symboles.

Sa langage et sa méthode rendent plus facile un essai de rapprochement et distinction de la théologie avec les sciences modernes. Cet experience ouvre la persone humaine à la contemplation de Dieu et son mystère, qui ne peut pas être fermé dans des concepts humains.

Lina Boff

Professora do Departamento de Teologia da PUC-Rio

Pós-doutora pela Pontifícia Universidade de Roma

Eva Aparecida Rezende de Moraes

Doutora em Teologia pela PUC-Rio

Professora do Departamento de Teologia da PUC-Rio

Professora do Instituto Teológico Franciscano de Petrópolis 


\section{Bibliografia de referência}

GREGORIO DI NISSA, bispo, l'ora di lettura commentata dai padre della chiesa, Bologna, Dehoniane, 1974-1976. Coleção de oito volumes com a colaboração de exgetas, comentaristas patrísticos, teólogos e teólogas.

GREGÓRIO DE NISSA, bispo, Liturgia das Horas/I-IV, Oficio das Leituras/I-IV, tradução oficial da CNBB, publicado em co-edição de Vozes, Paulinas, Paulus, Ave Maria, 1995.

, Omelie sul Cântico dei Cantici, a cura di Vincenzo Bonato, Bologna, Dehoniane, 1995. , Sull Anima e la Risurrezione, a cura di Ilaria Ramelli (texto greco a fronte), Milano, Bompiani, 2007. , em Patrologia, ALTANER, B. - STUIBER, A., São Paulo, Paulus, 1972, p. 306-311.

ORIGENE, Commento al Cantico dei Cantici, Roma, Cittá Nuova Editrice, 1976 (Collana di testi patristici)

\section{Dicionários}

MANZANARES, C. V., Dizionario sintético di Patristica, Cittá del Vaticano, Libreria, Editrice Vaticana.

DICIONÁRIO PATRÍSTICO E DE ANTIGUIDADES CRISTÃS, Petrópolis, Vozes e São Paulo, Paulus, 2002.

\section{Sobre TEOLOGIA}

AA.VV., La Costituzione Dogmática sulla Chiesa, Torino-Leumann, 1967.

ASSMANN, Hugo, "Paradigmas ou cenários epistemológicos complexos?". In: VV.AA., Teologia aberta ao futuro, Editora Soter/Edições Loyola, 1997, p. 41-66

ILLANES, J. L., SARANYANA, J. I., "Patrología, la edad de oro de la literatura patrística griega”, em BAC II, Madrid, 1985.

BOFF, Leonardo, Ecologia. Grito da Terra - Grito dos pobres, São Paulo, Editora Ática, 1995.

BOFF, Lina, "Índole escatológica da igreja peregrinante”, em: Atualidade Teológica, Ano VII, 2003, fasc. 13, p. 9-31.

BOFF, Lina e MORAES, Eva Aparecida Rezende, "A concepção de vida em Gregório de Nissa: Ensaio de aproximações com as ciências da vida”, em AtualidadeTeológica $\mathrm{n}^{\mathrm{o}} 27$, ano 11,2007 , p. 317-341

CHÊVENERT, J., L'Eglise dans le commentaire d'Origène sur le Cantique des Cantiques, Bruxelles, 1969.

CRUZ, da Eduardo Rodrigues, A dupla face: Paul Tillich e a ciência moderna ambivalência e salvação, São Paulo, Loyola, 2008. 
DANIÉLOU, J., Gregoyre de Nysse. La vie de Moyse ou traité de la perfection em matiére de vertu, SCH 1, Paris, segunda edição de 1955, corrigida e aumentada, Paris, 1968.

TODDE, M. e GHINI, Emanuela, comentaristas do texto patrístico em l'ora di lettura commentata dai padri della chiesa/2, Bologna, Dehoniane, 1976.

\section{Sobre as CIÊNCIAS DA VIDA:}

ATLAN, Henri, Entre o cristal e a fumaça, Jorge Zahar Editor, 1992.

BUNGE, Annik Vivier, Introdução à Química Quântica, Editora Edgard Blücher Ltda, 1977.

CAPRA, Fritjof, O Tao da Física, São Paulo, Editora Cultrix, 1983. , A Teia da Vida, São Paulo, Editora Cultrix, 2002.

,O ponto de mutação. A ciência, a sociedade e a cultura emergente, Editora Cultrix, 2003.

CHARDIN, Teilhard, La Place de l'Homme dans la Nature. Éditions du Seuil. Paris, 1956.

COLLINS, Francis S., A linguagem de Deus, São Paulo, Editora Gente, $2007^{2}$.

CURTIS, Helena, Biologi,. Editora Guanabara Koogan S. A., Rio de Janeiro. $1977^{2}$.

DELSEMME, Armand, Our Cosmic Origins, Cambridge University Press, 1998. DEVALL, Bill; SESSIONS, George, Deep Ecology, Salt Lake City, Utah. Peregrine Smith, 1985.

EISLER, Riane, The Chalice and the Blade, San Francisco, Harper \& Row, 1987.

EL-HANI, Charbel Niño; VIDEIRA, Antonio Augusto Passos (org.), O que é vida? Para entender a Biologia do século XXI, Editora Relume Dumará / FAPERJ, Rio de Janeiro, 2005.

EMMECHE, Claus; EL-HANI,Charbel Niño, "Definindo vida". In: EL-HANI, Charbel Niño; VIDEIRA, Antonio Augusto Passos (org.), O que é vida? Para entender a Biologia do século XXI, Editora Relume Dumará / FAPERJ, Rio de Janeiro, 2005.

FEYNMAN, R. P. Física em seis lições. Editora Ediouro. 2004.

FOLEY, Robert. Apenas mais uma espécie única. Edusp (Editora da Universidade de São Paulo). 1993

GOULD, Stephen Jay, In: ZIMMER, Carl, O Livro de Ouro da Evolução. O triunfo de uma idéia, Editora Ediouro, 2004.

HARAWAY, Donna Jeanne, Crystals, Fabrics and Fields: Metaphors of Organicism in Twentieth-Century Developmental Biology, New Haven, Yale University Press, 1976.

JUDSON, Horace Freeland, The Eighth Day of Creation. New York, Simon \& Schuster, 1979.

KÜHN, Thomas S., The Structure of Scientific Revolutions, Chicago, University of Chicago Press, 1962. 
LILIENFELD, Robert, The Rise of Systems Thory, New York, John Wiley, 1978. LOPES, José Leite, A Estrutura Quântica da Matéria. Do átomo pré-socrático às partículas elementares, Editora UFRJ, $2005^{3}$.

MACY, Joanna, World As Lover, World As Self, Berkeley, Califórnia, Parallax Press, 1991.

MERCHANT, Carolyn (org.), Ecology, Atlantic Highlands, Humanities Press, 1994. PETERS, Ted; BENNET, Gaymon (org), Construindo pontes entre a Ciência e a Religião, São Paulo, Editora UNESP, Edições Loyola 2003.

PIÉRON, Henri, L'Homme, rien que l'Homme, Presses Universitaires de France, 1967.

VIEYRA, Adalberto; SOUZA-BARROS, Fernando, "Teorias da Origem da Vida no Século $X X$ ”. In: EL-HANI, Charbel Nino; VIDEIRA, Antonio Augusto Passos (org.), O que é vida? Para entender a Biologia do século XXI, Editora Relume Dumará / FAPERJ, Rio de Janeiro, 2005.

VIDEIRA, Antonio Augusto Passos, "Para que servem as definições?". In: ELHANI, Charbel Niño; VIDEIRA, Antonio Augusto Passos (org.), O que é vida? Para entender a Biologia do século XXI, Editora Relume Dumará / FAPERJ, Rio de Janeiro, 2005.

ZEILINGER, Anton, A face oculta da natureza. O novo mundo da física quântica, Editora Globo, 2005.

ZOHAR, Dannah; MARSHALL, Ian, QS. O “Q” que faz a diferença, Rio de Janeiro, Editora Record, 2002. 